\title{
Pulmonary nodular lymphoid hyperplasia
}

INSERM

\section{Source}

INSERM. (1999). Orphanet: an online rare disease and orphan drug data base. Pulmonary nodular lymphoid hyperplasia. ORPHA:60026

Pulmonary nodular lymphoid hyperplasia (PNHL) is a reactive lymphoid proliferation manifesting as solitary or multiple nodules in the lung. 